This is the version of the chapter accepted for publication in Kim, Marie, (ed.), The Spirit of Korean Law. Leiden: Brill, pp. 83-103. (Brill's Asian Law Series)

https://doi.org/10.1163/9789004306011_005

Accepted version downloaded from SOAS Research Online: http://eprints.soas.ac.uk/23129

\title{
Confucian Ideology and Legal Developments in Chosŏn Korea: A Methodological Essay
}

\author{
Anders Karlsson, School of Oriental and African Studies
}

\begin{abstract}
"After all, progress is surely the product of all our joint efforts, so we can practically predict that any real progress is likely to be precisely what nobody wanted."

Robert Musil, The Man without Qualities
\end{abstract}

As is now well attested by a vast quantity of scholarship, the later half of the Chosorn dynasty (1392-1910) was a period of both wide-ranging socio-economic change and significant developments in Confucian statecraft. Recently also the legal system of the period has received increasing attention from legal scholars and historians analysing it within the context of these socio-economic changes and ideology construction. According to this research the period witnessed a number of significant reforms related to legal procedures and the administration of punishment. Most famous are the reforms related to judicial prudence and penal leniency carried out under the reigns of Yŏngjo (1724-1776) and Chŏngjo (1776-1800). These two kings indeed showed a keen interest in legal matters. Out of the thirty-six entries on prudence in punishment (hümhyul) in the Records of the Ministry of Punishment (Ch'ugwanji), twenty-two are from the reigns of these two kings, and in terms of entries related to the abolishment of various forms of punishment and torture (chehyong) the number is thirteen out of sixteen. ${ }^{1}$

Yŏngjo famously prohibited a number of torture methods. Torture in the form of flogging was sanctioned by law, but a number of extrajudicial forms of torture were also in practice. Although leniency played an important part in sage kingship, in Confucian legal thinking the correct application of punishment was more important, and Yŏngjo justified the prohibition with the fact that law did not sanction these forms of torture.

Since times of yore punishment has been within the law. If the practice is extrajudicial, then it runs against the principle of benevolence in punishment, even if it produces a swift and easy confession. And in days of yore, even if extra-judicial practices existed, they were seldom used and we should follow the prosperous example of previous dynasties. ${ }^{2}$

Knee-pressing (apsŭl) was prohibited in 1725, certain forms of leg-bending (churi) in 1732, branding (nakhyŏng) in 1733, and reckless beating (nanjang) 1765. Concerns for the physical wellbeing of his subjects were also a contributing factor to these rulings. When prohibiting reckless beating the king exclaimed:

\footnotetext{
${ }^{1}$ Ch'ugwanji, facsimile edition in three volumes (Seoul: Seoul National University, 2004).

2 Yŏngjo sillok 1733/8/22.
} 
Even the basest of man born with a healthy body would like to pass away with it intact. That is human nature. I am overwhelmed when I think of all innocent who have been subject to this punishment and have had their bodies harmed. Ah, I have been on the throne for forty-six years and have yet failed to exert humane rule and now in old days I decide to abolish a form of punishment that has not existed elsewhere. I have left the palace and made enquiries and everybody is of the same opinion, so from today I prohibit reckless beating, both in the capitol and in the provinces, so that our people can go and meet their fathers with their bodies intact. ${ }^{3}$

Yongjo also limited the number of times torture could be applied in one day and put restriction on the torture of women. ${ }^{4}$ His grandson and successor, Chŏngjo, continued this work and for the sake of the correct application of punishment regulated and standardized the tools used in punishment with the Hümhyul chönch'ik (Regulations Concerning Prudence in Punishment) from 1778.

Other noteworthy trends are the positive revaluation of litigations from being viewed as signs of social decay to be regarded as a proper means by which people could look after their rights and the strengthening of the legal power of magistrates undermining the power of yangban in the provinces. ${ }^{5}$ Significant changes in the procedures at the Office of Trial Processes (Ch'ugukch'ŏng) has also been observed. ${ }^{6}$ In the eighteenth century we can furthermore see efforts to straighten up the procedures regarding forensic investigations. The Chosón dynasty used a forensic handbook that was based on the Yuan coroner's guide Wuyuanlu (Coroner's Guide for the Elimination of Grievances). This was published with annotations in Korea in 1438 as the Sinju muwŏllok. In 1748, during the reign of Yŏngjo, it was revised and expanded on royal orders, and the resulting text was called the Chŭngsu muwŏllok. In the third month of 1784, King Chŏngjo lamented the fact that the procedures for investigating murders in the capital were not even up to standard with those in the countryside and gave some instructions on how these problems should be rectified and ordered that these should be issued as a royal edict. Fifteen days later detailed and specific regulations were promulgated for forensic investigations in the capital, the Kyŏngok kŏmhŏm samok. ${ }^{7}$ Furthermore, the Chüngsu muwŏllok from the reign of Yŏngjo was still difficult to work with, and yet another version was produced in 1796. In the meantime an $i d u$ version had also been prepared, the Chüngsu muwŏllok ŏnhae.

These developments have been covered in a vast number of studies on the legal history of the period - conducted by both legal scholars and historians - discussing the formation and revision of law codes, the institutions of the legal system, specific areas of law or punishment, the legal attitudes of rulers and intellectuals, and the interaction between social change and legal reform. ${ }^{8}$ Scholarly analysis of legal trends and developments is often

\footnotetext{
${ }^{3}$ Ibid., 1770/6/18.

4 Sim Chaeu, "Chŏngjodae 'Hŭmhyulchŏnch'ik' ŭi panp'o wa hyŏnggu chŏngbi” [The Systemization of Punishment Implements and the Promulgation of the Hümhyulchŏnch'ik during the Reign of Chŏngjo,] Kyujanggak 22 (1999): 144-5.

${ }^{5}$ Han Sanggwŏn, "Chosŏn sidae ŭi kyohwa wa hyŏngjŏng" [Edification and Penal Administration in the Chosŏn Period,] Yŏksa wa hyŏnsil 79 (2011).

${ }^{6}$ Kim Uch'ŏl, "Chosŏn hugi ch'uguk unyŏng mit kyŏran ŭi pyŏnhwa" [Late Chosŏn Changes in the Management of the Office of Trial Processes and Death Penalty Verdicts,] Minjok munhwa 35 (2010).

${ }^{7}$ Chŏngjo sillok 1784/03/27.

${ }^{8}$ See for example Chŏng Kŭngsik, “'Sugyo tŭngnok' ŭi naeyong kwa kach'i” [Content and Value of Sugyo tŭngnok,] Kyujanggak 39 (2011); Pak Sŏngmu, “Tasan ŭi hŭmhyul chŏngsin kwa pŏp ŭisik” [Tasan's Judicial Prudence and Legal Understanding,] Pŏpsahak yŏn'gu 18 (1997); Sim Chaeu, "Chosŏn sidae yŏnjwajoe ŭi
} 
focussed on the attitudes of rulers like Yŏngjo and Chŏngjo and influential intellectuals occasionally bringing the Great Man theory to mind - and based on evaluation of whether their emphasis was on rule by ritual/virtue (yech 'i/tǒkch'i) or rule by law (pöpch 'i), a central dichotomy in Confucian ideology. In relation to the eighteenth century, given a wide range of legal compilation activities (to be discussed below), the attention given to forensic investigations, the revaluation of litigations and the strengthening of the legal power of the local magistrates seem to indicate a shift towards the rule of law. However, Yŏngjo and Chŏngjo were kings very much engaged in legal matters and we can also observe the kings personally intervene in the legal process, taking moral norms and human sentiments into consideration and often over-ruling existing laws. Furthermore, given the attention given to judicial prudence and penal lenience, it has been argued that this was a period when the state showed a greater reluctance to resort to harsh corporal punishment. ${ }^{9}$ While this certainly seem to be the case, it has also been suggested that capital punishment in the form of hyosu (the practice of displaying the decapitated head) was more widely used for its deterrent effect in Late Chosonn to protect the state's economic and political interests faced with an diversified population and economy, a trend that seemingly runs counter to the increasing reluctance to use harsh physical punishment. ${ }^{10}$ It has also been pointed out that the apparently benevolent rulings of King Yŏngjo, prohibiting forms of torture, were made against the background of his own harsh treatment and punishment of those who challenged his rule. ${ }^{11}$

The period thus provide a rather mixed picture and scholars have understood the nature of the observable changes quite differently, although they share a focus on Confucianism and the ideological aspects of law and punishment. In legal scholarship the focus has often been on the ideological emphasis on rule by virtue and the personal legal power of the king, as well as the role of the law to protect the position of the yangban elite. While arguing that this should not lead to negative evaluations of the legal culture of traditional Korea, Cho Chiman has argued that the further we get into the Chosonn dynasty the less rule was based on the system and increasingly became dependent on personal rulings, and while acknowledging that the legal reforms of the eighteenth century were sincere efforts to establish a Confucian penal order, Sim Hŭigi argues that their character at the same time was conservative and an effort to protect the "backward" yangban-dominated social order. ${ }^{12}$ Although historians working on legal matters of the period also put emphasis on the ideological aspects of law, they often come up with a more positive evaluation of eighteenth-century legal reforms. Han Sanggwŏn, for instance, rather sees a shift towards the rule by law, and argues that these reforms were part of the ideologically driven efforts to "suppress the strong and support the weak" (ókkang puyak ron). ${ }^{13}$ Sim Chaeu also gives a very positive evaluation of these reforms, arguing that Yŏngjo and Chŏngjo did not leave the ideological notion that the people is the basis of the

silsang: "Yŏnjwaan punsŏk ŭl chungsim ŭro" [The Reality of Guilt by Association in the Chosŏn Period: An Analysis of Yŏnjwaan,] Han'guk munhwa 55 (2011); O Yǒnggyo, ed., Chosǒn hugi ch'eje pyǒndong kwa Soktaejǒn, Seoul: Hyean, 2005.

${ }^{9}$ Sim Chaeu, "Chosŏn sidae pŏpchŏn p'yŏnch'an kwa hyŏngsa chŏngch'aek pyŏnhwa" [The Compilation of Law Codes and Changes in Criminal Policy in Chosŏn Korea,] Chindan hakpo 96 (2003).

${ }^{10}$ Anders Karlsson, "'Scions of Wealthy Families do not Die in the Marketplace': Death Penalty and Hyosu Punishment in Seventeenth and Eighteenth Century Chosŏn Korea”, in Capital Punishment in East Asia, ed. Itaru Tomiya (Kyoto: Kyoto University Press, 2012).

${ }^{11}$ Cho Yunsŏn, "Yŏngjodae namhyŏng, hokhyŏng p'yeji kwajŏng ŭi silt'ae wa hŭmhyul e taehan p'yŏngka" [The Process of Prohibiting Excessive and Cruel Punishments during the Reign of Yŏngjo and an Evaluation of his Judicial Prudence,] Chosŏn sidae hakpo 48 (2009).

${ }^{12}$ Cho Chiman, "Chosŏn sidae pŏp munhwa" [Legal Culture of the Chosŏn Period,] Pŏp kyoyuk yŏn'gu 3:1 (2008); Sim Hŭigi, "18 segi ŭi hyŏngsa pŏpchedo kaehyŏk" [Eighteenth Century Reforms of the penal Administration and Legal System,] Han' guk munhwa 20 (1998).

${ }^{13}$ Han Sanggwŏn, "Chosŏn sidae kyohwa wa hyŏngjŏng," 271-303. 
country as a formalistic discourse, but filled it with actual content. In these developments he sees parallels with European enlightenment and the abolishment of torture, although the drive in the Korean case came from the top (that is, the king) rather than from the bottom (that is, the emerging bourgeois class), as allegedly was the case in Europe. ${ }^{14}$

Although the basic understanding of these developments and the resulting conclusions are different, these two approaches share the perception that legal change is a purposive process, mainly ideologically driven. This essay, however, argues that to get a better understanding of legal developments in Chosŏn we must, on the one hand, acknowledge the wide range factors beyond the attitudes of kings and intellectuals that influenced these developments, diluting the purposiveness of the process, and on the other hand look beyond Confucianism, that is, challenge the explanatory prerogatives of ideology. A first step in addressing the variegated nature of legal developments would be not to conflate state interests with the interests of the social elite. One aspect that arguably has not been taken sufficiently into consideration in existing scholarship on Chosŏn legal history is the state and its need to mobilise the law and punishment to protect social order (as defined by the state) and its interests, a basic function of law. We should be open to the possibility that the state was an autonomous actor not only influenced by the social situation surrounding it, but also shaping social and political processes. Focussing on state capacities, and seeing ideology as one of a set of possible tools employed by the state in its efforts to control society could help us get a broader understanding of Confucianism and legal developments. Admittedly, works by historians argue that the legal reforms of late Chosonn was an effort to curb the power of the elite and protect the common people, but the focus often tend to be on ideologically charged promulgations made by kings rather than the actual execution of law by the state.

Few scholars would argue against the position that Confucianism exerted an immense influence on Chosŏn politics and society. We should, however, be careful not to explain all the actions of the Chosonn state in the name of this ideology. Even Martina Deuchler, who has been very influential with her work The Confucian Transformation of Korea, elsewhere cautions against the creation of a Foucauldian "truth regime" and stresses the need to look at the "logic of practice" in the application of Confucian notions. ${ }^{15}$ In a short essay legal scholar David Ibbetson has formulated a methodology for comparative legal history that is useful for the purpose of this study and its aim to approach such logic of practice in legal reform and legal developments. One simple but pertinent observation that Ibbetson makes is that when approaching law we must pay attention to two levels: "first, the level of legal doctrine, "law in the books'; and second, legal outcomes, the decisions in actual cases." ${ }^{16}$ Furthermore, even in terms of the actual law codes caution is needed. As Ibbetson points out:

\section{A provision in a code or a piece of legislation will have a strong authoritative force; but it may have become encrusted with explanatory rules which mean that it cannot be interpreted literally; or the legal system of which it is a member may}

\footnotetext{
${ }^{14}$ Sim Chaeu, "Chŏngjodae 'Hŭmhyulchŏnch'ik' ŭi panp'o wa hyŏnggu chŏngbi”; Sim Chaeu, "Chosŏn sidae pŏpchŏn p'yŏnch'an kwa hyŏngsa chŏngch'aek pyŏnhwa." As for the European case, the notion that the abolishment of torture in the eighteenth century was a result of Enlightenment thought has been challenged. See for instance John H. Langbein, Torture and the Law of Proof: Europe and England in the Ancien Régime (Chicago: Chicago University Press, 1977).

${ }^{15}$ Martina Deuchler, "Is 'Confucianization of Korea' a Valid Concept of Analysis," Sungkyun Journal of East Asian Studies 7:2 (2007).

${ }^{16}$ David Ibbetson, "Comparative Legal History: A Methodology," in Making Legal History: Approaches and Methodologies, ed. Anthony Musson and Chantal Stebbings (Cambridge: Cambridge University Press 2012), 135.
} 
contain higher-level rules, such as those contained in a constitution or a bill of rights, which potentially undermine the authority of a formal rule; or there may be rules providing for the annulment of legislation through desuetude [...] A further facet of the level of legal doctrine, of great importance to the historian, is the degree to which it allows a substantial measure of indeterminacy [...] it has to be recognised that at any one time there may be a number of possible rules, or formulations of rules, competing with each other. ${ }^{17}$

Another pertinent observation made by Ibbetson is that the two levels can develop independently of each other and that changes in legal outcomes do not necessarily have to be preceded by (ideologically dictated) reforms in legal doctrine.

From the point of view on legal history, this [the indeterminacy of legal doctrine] is the central feature that enables any system to adjust to changes in social, political and economic circumstances without formally having to depart from what has been done in the past; to put it another way, as result of this indeterminacy, a legal system can simultaneously be highly conservative and highly responsive to changes in the environment in which it operates. ${ }^{18}$

When approaching legal developments we must therefore be careful not to focus excessively on the level of doctrine but must also pay careful attention to developments on the level of legal outcomes, developments that might or might not be related to changes in the level above. The purpose of this essay is to address some methodological issues in the study of the relationship between Confucian ideology and legal developments in Chosŏn dynasty Korea in relation to the methodological approach introduced above. Although it analytically will be more focussed on late Chosŏn, it will discuss the earlier part of the dynasty in an effort to establish the analytical framework. The discussion is situated within the larger context of statecraft developments in the period and the intricate interaction between ideology-driven policy changes and other changes responsive to trends in society. Maintaining that much of existing scholarship has focussed too much on the influence of certain central tenets in Confucian ideology, the essay takes as its basic premise the position that we need to both get a more comprehensive understanding of the relationship between Confucian ideology, statecraft and law and approach law on two levels, legal doctrines and legal outcomes, acknowledging that the process of legislation was influenced both by ideological concerns and socio-political and socio-economic developments on the level of legal outcomes. It is beyond the scope of this essay to detail all aspects of such a comprehensive approach to the relationship between ideology and legal change, and it is therefore limited to two parts: a brief discussion on Confucian ideology and law, and a survey of legislation throughout the dynasty to indicate the complex textual basis for the level of actual legal outcomes.

\section{Confucianism, statecraft and law}

There is a consensus in both Korean and Western scholarship on Korean history that the introduction of Neo-Confucianism in late Koryŏ and the adoption of Confucianism as the state ideology for the Chosŏn dynasty had significant influence on historical developments on the Korean peninsula. In the early years of the dynasty the political system was reformed to

\footnotetext{
${ }^{17}$ Ibid., 136.

18 Ibid., 136-7.
} 
reflect the stronger emphasis on Confucianism, and early social legislation later led to what Martina Deuchler has labelled the "Confucian transformation of Korea". ${ }^{19}$ The fifteenth century saw the reign of King Sejong (r. 1418-1450) who based his rule on Confucian scholarship, and the sixteenth century saw the golden age of Chosŏn Neo-Confucian philosophy with iconic scholars like Yi Hwang (1501-1570) and Yi I (1536-1584) setting the themes for philosophical discussion for later periods. However if we look at scholarship over the years there is less of a consensus as to the influence of Confucianism on developments in the latter half of the Chosonn dynasty. In the wake of the soul searching after Koreas loss of independence to Japan in the early twentieth century it was often the Confucian political culture of the yangban elite that was put to blame, and also in Japanese colonial historiography it was this culture that was blamed for the "stagnancy" of Korea. Therefore post-liberation nationalist historiography sought the signs of dynamism and historical development in the demise of the existing system; orthodox Neo-Confucianism challenged by new more practical thought and the yangban elite challenged by other social forces. The internal development theory that grew strong in South Korea in the 1970s would be a continuation of this attitude, as would the minjung (people's) historiography of the 1980s.

Since the 1990s, however, Confucian ideology and Confucian statecraft in Chosŏn Korea has started to be revaluated. This is, of course, partly related to the positive revaluation of Confucianism in the larger region, and in Korean scholarship it has specifically led to a revival of political and institutional history and a focus on the $18^{\text {th }}$ century, in particularly the reigns of Yŏngjo and Chŏngjo. In this scholarship Confucian ideology is seen as having a positive influence on political developments in the period. Whereas the internal development theory and minjung historiography saw the roots of Korean modernity in the demise of Confucianism, many scholars in this new line of scholarship would rather argue that this ideology in fact facilitated the emergence of modernity, as reflected in state policies accommodating the voices of social groups below the yangban elite or looking after the weak in society, or in the emergence of a public sphere and civil society.

A similar development can be seen in the approach towards legal history. It has been pointed out that early Western scholarship had little understanding of or even interest in the legal aspects of the East Asian Confucian statecraft tradition, sometimes going so far as to claim that there existed no law in the Western sense. ${ }^{20}$ Pondering on the reason why Western scholarship on China for a long time had little to say about its legal system, William P. Alford partly explain this with the outlook of the scholars of the Great Tradition school and their focus on state ideology and the writings and activities of the educated elite. ${ }^{21}$ Law was therefore not dealt with as an independent important part of statecraft but subsumed under Confucian attitudes towards it, be that by statesmen or intellectuals. Furthermore, maintaining that there existed no civil law, that the legal system was exclusively penal, many scholars portrayed law as simply a tool for suppressive rule by the state. Also in early Korean legal scholarship, pre-modern Korean law was predominantly dismissed simply as a tool for oppressive social control or subject to unfavourable comparisons with the alleged standards of Western legal culture. One of the earliest extensive English-language treatments of Korean legal traditions states:

\footnotetext{
${ }^{19}$ Son Pogi, Social History of the Early Chosŏn Dynasty: The Functional Aspects of Governmental Structure, 1392-1592 (Seoul: Jisik-sanup Publications, 2000); Martina Deuchler, The Confucian Transformation of Korea: A Study of Society and Ideology (Cambridge, Mass: Council of East Asian Studies, Harvard University, 1992).

${ }^{20}$ Teemu Ruskola, "Legal Orientalism," Michigan Law Review 101:1 (2002).

${ }^{21}$ William P. Alford, "Law, Law, What Law?: Why Western Scholars of Chinese History Have Not Had More to Say about Its Law," Modern China 23:4 (1997).
} 
In the olden days, before the introduction of a European legal system, the law [in Korea] was an instrument for governing the people. The law was for the benefit of the ruler, never for the benefit of the ruled. When necessary, the ruler never hesitated to disregard the law, for he was the one who promulgated it and he did so for the sole benefit of himself. [...] A legal obligation on the part of a ruler was a contradiction in terms, as far as a Korean was concerned. A moral obligation or perhaps an obligation to Heaven may be said to exist, but never a legal obligation. ${ }^{22}$

Since some time ago now scholars have started to revaluate the characteristics of law in East Asia and its position in Confucian statecraft. Philip C.C. Huang, for instance, early argued for the existence of civil law in China and portrayed a less monolithic picture of the exercise of law, and more recently Jiang Yongling has convincingly shown how law functioned within the larger cosmological normative order of East Asia. ${ }^{23}$ In connection with Chosŏn Korea, Hahm Chaihark has suggested that ritual "as the basis for political legitimacy" carried "constitutional potential for restraining and disciplining power." 24 Other research has argued that the Chosón state when applying the law to protect itself and its system had to a certain extent itself adhere to the norms and values of the Confucian ideology underpinning the system. ${ }^{25}$ Research has also shown popular agency in the legal system, and that despite the Confucian bias against litigations the Chosŏn period saw people making use of litigations to a larger extent than previously recognised. ${ }^{26}$

As briefly discussed above, another related theme in the understanding of law in a Confucian polity has been the two bipolar notions of rule by ritual/virtue and rule by law.

Direct them [the people] by laws, regulate them with punishments-the people will seek to avoid [punishments] and will be without shame. Direct them [the people] with moral force, regulate them with ritual-the people will possess shame, and moreover will be righteous. ${ }^{27}$

\section{Through punishment there may come to be no punishments. ${ }^{28}$}

These two quotes, the first from the Analects and the second from the Book of Documents, have exerted great influence on the understanding of law in a Confucian polity establishing a bipolar constellation of Confucians suspicious of statecraft based on law and reluctant to

\footnotetext{
${ }^{22}$ Hahm Pyong-Choon, The Korean Political Tradition and Law (Seoul: Royal Asiatic Society, Korea Branch, 1967), 207. For a similar attitude, see also Bong Duck Chun, "Legal Attitudes of the Late Yi Dynasty," in Traditional Korean Legal Attitudes, Bong Duck Chun, William Shaw and Dai-Kwon Choi (Berkeley: Institute of East Asian Studies, University of California, Berkeley, 1980).

${ }^{23}$ Philip C.C Huang, "Between Informal Mediation and Formal Adjudication: The Third Realm of Qing Civil Justice," Modern China 19:3 (1993); Jiang Yonglin, The Mandate of Heaven and The Great Ming Code (Seattle: University of Washington Press, 2011).

${ }^{24}$ Chaihark Hahm, "Ritual and Constitutionalism: Disputing the Ruler's Legitimacy in a Confucian Polity," The American Journal of Comparative Law 57:1 (2009).

${ }^{25}$ Anders Karlsson, "Law and the Body in Joseon Korea: Statecraft and the Negotiation of Ideology," The Review of Korean Studies 16:1 (2013).

${ }^{26}$ Cho Yunsŏn, "Soktaejŏn hyŏngjŏn ch'ŏngnijo wa min ŭi pŏp ŭisik" [The Article on Proper Handling of Litigations in the Penal Section of Soktaejŏn and People's Understanding of Law,] Han'guksa yŏn'gu 88 (1995); Sim Chaeu, "Chosŏn hugi sosong ŭl t'onghae pon pŏp kwa sahoe" [Law and Society as Seen through Late Chosŏn Litigations,] Tongyang sahak yŏn'gu 123 (2013).

${ }^{27}$ The Analects 2.3 .

${ }^{28}$ The Book of Documents, "Counsels of the Great Yu".
} 
apply punishment versus the legalists who advocated the use of law and punishment. Even if such ideological notions were used when discussing legal matters at court, this simplistic divide is not very helpful if we want to understand the role of law and punishment in actual Confucian statecraft. Although tension existed ideologically in Confucianism between rule by ritual/virtue and rule by law, in actual statecraft punishment was considered to be an important and indispensible supplement. In Chosŏn Korea King Sejong emphatically stated:

\begin{abstract}
Punishment is a tool to help statecraft, so even in the ancient times of flourishing civilization it could not be completely abolished. When Shun became the Son of Heaven he could only be moderate in the usage of punishment, and when Gao Yao became minister he assisted the five teachings by clarifying the five punishments and dexterously combined the two to achieve enlightened statecraft. Ah, how it flourished! But as we reach Shi Huangdi of Qin brutality started to be worshipped and the gang of Zhao Gao employed cruel and cursory laws so that the wise benevolence was lost and the state collapsed after only its second generation. How can we not take warning from this? ${ }^{29}$
\end{abstract}

In this quote Sejong stresses the need for appropriate application of law and punishment and in this echoes the approach to law and punishment of the Song dynasty Neo-Confucian scholar Zhu Xi (1130-1200) who in his comments to the above passage in the Analects said: "Laws and regulations are tool of governance. Punishments are complementary methods of governance." ${ }^{30} \mathrm{Zhu} \mathrm{Xi}$ agreed that ritual and virtue were at the root at good governance and that rulers could not rely solely on regulations and punishment, but at the same time he also argued that it was impossible to depend solely on rituals and virtue without the backing of law and punishment. ${ }^{31}$ The legal thought of $\mathrm{Zhu} \mathrm{Xi}$ is of course highly relevant for Chosón given the high degree of authority the thought of this Neo-Confucian scholar wielded there, and his authority was indeed frequently referred to at the Chosŏn court when discussing legal matters. ${ }^{32}$ Norman P. Ho has summarised Zhu Xi's views as follows:

\begin{abstract}
Zhu Xi supported utilizing law not just to evoke fear of punishment in people, but more importantly, to assist in the moral education of the populace. Law for him was intertwined closely with Confucian principles. As such, laws should be clear, streamlined, and transparent, to enhance their pedagogical power. Law and legal punishments are also further elevated and empowered in the passage above because Zhu Xi directly equated one of law's goals with the preservation of the Principle of Heaven. Indeed, Zhu Xi maintained that law itself is Principle (li), as everything contains li, and that all the li in this world is uniform. Thus, as we can see, Zhu Xi envisioned a legal system that interacts and is engaged with morality. Law, rites, virtue, and morality all work together in order to bring the people to goodness and promote social order and harmony. ${ }^{33}$
\end{abstract}

In actual statecraft rule by ritual/virtue and rule by law should therefore not be seen as the two ends of a bipolar constellation, and in the case of Chosonn Korea Kim Ho rightly argues that rule by virtue and rule by law should rather be seen as two sides of the same coin. For late

\footnotetext{
29 Sejong sillok $1431 / 6 / 2$.

${ }^{30}$ Quoted in Norman P. Ho, “The Legal Philosophy of Zhu Xi (1130-1200) and Neo-Confucianism's Possible Contribution to Modern Chinese Legal Reform," Tsinghua China Law Review 3 (2011), 187.

${ }^{31}$ Ho, "The Legal Philosophy of Zhu Xi," 188.

${ }^{32}$ See for instance the discussion on the mutilation of thieves in which the advocates for this harsher form of punishment mobilised the views of Zhu Xi. Karlsson, "Law and the Body in Joseon Korea".

${ }^{33}$ Ho, "The Legal Philosophy of Zhu Xi," 189.
} 
Chosŏn he observes an emphasis on Confucian morals and edification and argues that this should not be seen as representing arbitrary and personal rule, but rather as an effort to create a legal culture based on wide-spread consensus on the moral principles and human sentiments that should be taken into consideration in conjunction with the law. So in a sense late Chosón legal reforms were both about strengthening the rule by virtue, and strengthening the legality of political power. ${ }^{34}$

Since punishment was considered an inseparable part of statecraft, the approach to law was more practical than the focus on the bipolar ideological notions of rule by virtue versus rule by law seem to indicate. New legislation was often a reaction to actual cases or social trends and the broader statecraft ramifications were taken into consideration. Rule by virtue and rule by law were two ideological tools that were mobilised to justify the practical legal solution rather than ideological positions driving the development in certain directions. ${ }^{35}$

\section{Chosŏn legal developments}

In terms of scholarship on the legal system of early Chosonn the research has predominantly been conducted on the level of doctrine and focus has been on the influence of the introduction of Confucianism as state ideology. Apart from the basic reason that we lack sources on the second level for this period - except references to high profile cases in the veritable records - this situation seemingly is linked with the notion that this is when the "Confucianization" of Korea commenced. Of course, the early part of the dynasty would be a period of extensive legislation and government-led legal reform.

Lamenting the confusion of the legal system in Late Koryŏ, the founder of the Chosŏn dynasty, King T'aejo (r. 1392-1398), in his inaugural proclamation stipulated that judicial officials in the capital and the provinces should refer to the Great Ming Code (Da Ming lï) in all criminal cases. ${ }^{36}$ Given the difficulties in applying a foreign law text to Chosŏn this code was translated into vernacular Korean with $i d u$ in 1395, Koreanizing names of government agencies and titles. This translation was later revised by among others Chŏng Tojŏn (13421398), the "architect of the Chosonn dynasty", and published in more than 100 copies as the Taemyŏngnuyl chikhae (Literal Explanation of the Great Ming Code). ${ }^{37}$ Having the Ming Code as its basic civil and penal code, the new dynasty of course also needed a dynastic code stipulating its institutional structure. The process of producing a long-lasting code however proved to be cumbersome and the early part of the dynasty saw continuous efforts at this. The preparatory work had been commenced early on by Chŏng Tojŏn, who in 1394 privately compiled a text on the governance of the country, the Kyŏngguk yukchŏn (Six Codes for Administering the Country). This text is said to have been used as reference when Kyŏngje yukchŏn (Six Codes of Administration), the first dynastic code, was compiled in $1397 .{ }^{38}$ As this was an intensively formative period for the new dynasty the code was repeatedly supplemented with new texts during the reigns of T'aejong and Sejong. ${ }^{39}$

\footnotetext{
${ }^{34}$ Kim Ho, "Hŭmhŭm sinsǒ ŭi il koch'al: Tasan ŭi kwaosal haesŏk ŭl chungsim ŭro" [A Study on Hŭmhŭm sinsŏ: Focussing on Tasan's Analysis of Involuntary Manslaughter,] Chosŏn sidaesa hakpo 54 (2010).

${ }^{35}$ For a discussion on such "negotiation of ideology" see Karlsson, "Law and the Body in Joseon Korea".

${ }^{36}$ T'aejo sillok 1392/07/28.

${ }^{37}$ For a good introduction to the reception of the Great Ming Code, see Cho Chiman, "Chosŏn ch'ogi

'Taemyŏngnyul' ŭi suyong kwajŏng" [The Reception Process of the Great Ming Code in Early Chosŏn,]

Pŏpsahak yŏn'gu 20 (1999).

${ }^{38}$ T'aejo sillok 1397/12/26.

${ }^{39}$ T'aejong sillok 1412/04/14; 1413/02/30; Sejong sillok 1426/12/03,15; 1431/05/13; 1433/01/04.
} 
But the work of establishing a permanent code would continue. After King Sejo (r. 14551468) had usurped the throne in 1455 much new legislation was enforced and it was felt that it was no longer sustainable to keep publishing supplementary codes and that an "eternal law code" (manse sŏngbŏp) was needed. A compilation agency (Yukchŏn sangjŏngso) was thus established to produce a new, unified code. In 1460 the Section on Taxation (Hojŏn), was completed, to be followed the following year by the Section on Punishment (Hyŏngjŏn). Then in 1466 the remaining Sections on Personnel (Ijŏn), Rites (Yejŏn), Military Affairs (Pyŏngjŏn) and Public Works (Kongjŏn) were completed. It was decided that the two first sections should be looked over again and that the complete Code be put in force from 1468 . However, King Sejo foresaw problems and decided to postpone its distribution. King Yejong (r. 1468-69) also established a compilation committee but passed away before he was able to publish a new code. When King Sŏngjong (r. 1469-94) was enthroned the revision continued and finally in 1471 a new unified code was promulgated, the Kyŏngguk taejŏn (Great Code for Administering the Country). Still more revision was needed, however, and a new version was promulgated in 1474. The latter had been promulgated together with a supplement of seventy-two paragraphs, and in 1481 it was decided to once again rework the code a produce a unified version. This was completed in 1485 and this version is the oldest extant dynastic code.

As for continuous legislation, principally royal orders carried the power of law. The reception of these in the form of edicts (sugyo) by relevant agencies constituted the basic form of the law. In the process of their enforcement these edicts were sorted in documents setting the example for how an issue should be dealt with (sarye), or for special matters in the form of regulations (samok or chŏlmok). Many royal edicts were of provisional character and were not perpetuated as laws. For those that were, however, the first stage was the formulation of paragraphs of more legal character (chorye, choryŏng, chohoek, chokkŏn, chogyŏk etc). If the edicts were of a more permanent character the formulation of rules (singnye or kyŏksik) would follow, and finally for general and permanent rules the formulation of laws (pómnyŏng or pöpkyu). We thus have a wide range of edicts, regulations, rules and laws that originates from royal orders and carries legal character. Often the source of this new legislation would be royal rulings on actual cases.

The Great Ming Code was kept as the main penal code, but the Chosŏn state needed to deal with the growing number of such edicts, regulations, rules and laws. These would later be systemised in supplements to the dynastic code (songnok) and edict collections (chimnok). The first supplementary code, the Taejŏn songnok (Expansion of the Kyŏngguk taejŏn), was produced not long after the unified code had been promulgated. It contains royal edicts considered to be of permanent character that had been issued since the compilation of Kyŏngguk taejŏn and additional regulations needed for the enforcement of the dynastic code. Due to the political turmoil during the reign of Yŏnsan'gun (r. 1494-1506) it was considered that the legal texts needed to be systemized again and arguments for a new supplementary code appeared. A second supplementary code was thus compiled in 1502, but as it was considered to contain some problems it was not printed until the following year. There were still many protests, however, and many of the laws contained in it were abolished by royal edicts and this text never gained enough authority to function as a proper supplementary code. A new supplementary code was instead compiled in 1543 on order by King Chungjong (r. 1506-1544), the Taejŏn husongnok (Later Expansion of the Kyŏngguk taejŏn). 
After the Taejŏn husongnok no more supplementary codes were promulgated, and new edicts were instead gathered in edict collections. These differed from the supplementary codes in that they simply just gathered edicts whereas the latter had picked those of permanent character. Many of the edicts in the edict collections were thus later not included when new law codes were compiled. These collections are thus important sources to both get a closer look at how new legislation developed before being settled in a code, and to get a better understanding of the situation at a specific time. The first of these was the Kaksa sugyo (Royal Edicts Received by Various Government Agencies). We saw above that sugyo were the royal edicts as they were received by relevant government agencies and in this collection they thus are in the form of the documents, the kyeha munsŏ, the Royal Secretariat (Sungjŏngwŏn) forwarded to the various government agencies. There is no information as to when and by whom this collection was made, but some hints are given by the dating of the edicts carried. The main part contains edicts issued between 1546 and 1571 and it thus seems that a first compilation was performed in the early 1570 s.

The above has been a survey of the compilation of legal texts in early Chosorn. The scholarly understanding of the legal history of this period corresponds with the picture of the overall historical development described above; that is, also legally this was a period of Confucianization and the establishment of the "Kyŏngguk taejŏn system". ${ }^{40}$ It is argued that the basic characteristic of this new system was Confucian "rule by ritual" as reflected in legislation. ${ }^{41}$ While this essay acknowledges the influence of Confucian ideology in the period, the above narration of the development of the dynastic code indicates how complicated the textual basis for the legal system was in early Choson. One the one hand we have the relationship between the Great Ming Code and the penal code of the Kyongguk taejŏn. The general scholarly understanding is that although the Great Ming Code was the basic penal code, in those cases where laws in the two texts contradicted each other, the laws in the dynastic code should be given precedence, but the actual situation is often not that clear. Also, in terms of the role of the introduction of the Great Ming Code in terms of the Confucianization of Korea, we must remember that some of the laws actually were revised to conform better to Korean social norms. ${ }^{42}$ Furthermore, Han Sanggwŏn has shown that King Sejong drew from an even wider set of Chinese texts, preceding the Great Ming Code, in his legal reforms. His research also successfully shows how legislation during the reign of Sejong was a mix of benevolent Confucian rule and the application of harsh corporal punishment (mutilation) that generally was condemned in Confucian rhetoric. ${ }^{43}$ Tellingly, in the discussions surrounding the punishment of thieves, often the name of Zhu Xi was evoked and his call for a strict and clear legal system in which punishments had an indispensable role

\footnotetext{
${ }^{40} \mathrm{O}$ Yǒnggyo ed., Chosǒn kǒn'guk kwa Kyǒngguk taejǒn ch'eje ǔi hyǒngsǒng [The Establishment of Chosŏn and the Formation of the Kyǒngguk taejón System] (Seoul: Hyean, 2004).

${ }^{41}$ Ch'oe Yŏnsik and Song Kyŏngho, “'Kyŏngguk taejŏn' kwa yugyo kukka Chosŏn ŭi yech'i: ye ŭi hyŏngsik hwa kwajŏng ŭl chungsim ŭro" [Kyŏngguk taejŏn and the Rule by Ritual of the Confucian State of Chosŏn: Focusing on the Formalisation of Ritual,] Sahoe kwahak nonjip 38:1 (2007); Pak Hyŏnmo, "Kyŏngguk taejŏn ŭi chŏngch'ihak: Yech'i kukka ŭi inyŏm kwa silche” [The Political Science of Kyŏngguk taejŏn: The Ideology and Reality of a Rule by Virtue State,] Han'guk chŏngch'i yŏn'gu 12:2 (2003); Kim Yŏngsu, "Sejong taewang ŭi pŏp kwa chŏngch'i: Yuhakchŏk 'yech'i chuǔi' ŭi isang kwa hyŏnsil" [The Law and Politics of King Sejong the Great: The Ideal and Reality of the Confucian Ideology of Rule by Ritual,] Tongyang chŏngch'i sasangsa 6:1 (2007).

${ }^{42}$ Cho Chiman, Chosŏn sidae ŭi hyŏngsabŏp: Taemyŏngnyul kwa kukchŏn [Chosŏn Period Criminal Law: The Great Ming Code and the Dynastic Code] (Seoul: Kyŏngin munhwasa, 2007).

${ }^{43}$ Han, Sanggwŏn, "Sejongdae ch'idoron kwa Taemyŏngnyul: Chŏldo sambŏmja ch'ŏbŏl ŭl tullŏssan nonbyŏn ŭl chungsim urro" [The Great Ming Code and the Discourse on the Punishment of Theft during the Reign of Sejong: Focussing on the Discussions surrounding the Punishment of Three Time Offenders,] Yǒksa wa hyŏnsil 65 (2007).
} 
to play. ${ }^{44}$ This indicates that even if we accept the argument that this was a period of Confucianization of the legal system and that the ideological rhetoric at court centred on rule by ritual, we must be careful not to assume that the legal system as such was a direct reflection of this. However, since we unfortunately do not have much sources on the "legal outcomes' of the period, a more comprehensive understanding of the legal system/culture is difficult to arrive at.

If we move on to late Chosŏn and in particular the eighteenth century, this is for various reasons a very interesting period for the study of Korean legal history. It was a period characterized by developments in Confucian statecraft. Partly influenced by developments in Qing China, intellectuals discussed how statecraft best could benefit the country and its people, and the two kings Yŏngjo and Chŏngjo are famous for their efforts at creating a Confucian political order. Prior to the eighteenth century legal developments followed previous patterns in that royal edicts went through various levels of codification. Towards the end of the seventeenth century arguments were therefore raised for a new collection of these. The new collection, the Sugyo chimnok (Collection of Royal Edicts), was compiled in 1698. Many of the royal edicts that had been issued after the Taejon husongnok were scattered and lost and central government felt a need to make a comprehensive collection. All edicts found in both central and provincial agencies were thus collected and compiled. This collection therefore contains royal edicts issued during the 155 years after the promulgation of the Taejŏn husongnok up till 1698. Arguments to compile a new collection were again raised in 1732, and this would in the end lead to the compilation of Sinbo sugyo chimnok (New Expanded Collection of Royal Edicts). This collection contains edicts issued after the compilation of Sugyo chimnok up till 1743. When we reach the eighteenth century, a period of extensive legal reform, we see revisions of the dynastic code. ${ }^{45}$ These edicts would later be fully codified, this time in the Soktaejön (Supplement to the Great Code) of 1746. As we can see from its title, in character it was supplement, but it was given code status. Working with two codes, of course, caused problems and during the reign of King Chŏngjo efforts began to produce a new unified code. This was the Taejŏn t'ongp'yŏn (Comprehensive Edition of the Great Code) of 1785.

Due to the principle that the decisions by predecessor could not be challenged, these revised law codes did not eliminate any old regulations, but rather simply added new laws and indicated when the law had been added. The result of all this is that there really was no 'letter of the law'. Not only was the Great Ming Code supplemented and potentially contradicted by an ever-growing penal code in the dynastic code, but the existence of royal edicts in various degrees of codification also meant that adjudicators had to refer to a vast number of legal sources. Even if royal edicts carried the power of law, they functioned within a very complex web of legal sources and consequently we should be careful to not to assume that ideologically charged promulgations by the king directly changed legal practices.

Given this complex situation a number of comprehensive legal reference works were also compiled throughout the eighteenth century to assist adjudicators. The first of these was the Chöllok t'onggo (Conspectus of Code and Precedents) compiled upon orders from King Sukchong (r. 1674-1720). The compilation was ordered in 1701 and completed in 1706. This text was later expanded during the reign of King Yongjo with the compilation of the

\footnotetext{
${ }^{44}$ Karlsson, "Law and the Body in Joseon Korea".

${ }^{45}$ Hong Sunmin, "Chosŏn hugi pŏpchŏn p'yŏnch'an ŭi ch'ui wa chŏngch'i unyŏng ŭi pyŏndong” [Trends in Late Chosŏn Law Code Compilation and Changes in Political Management,] Han'guk munhwa 21 (1998).
} 
Chŭngbo chŏllok t'onggo (Expanded Conspectus of Code and Precedents). Another reference work was compiled during the reign of King Yŏngjo, the Paekhŏn ch'ongyo (Collected Essentials of the Hundred Laws). The problem with the comprehensive survey Chollok t'onggo had been that it contained laws no longer in force, and Paekhön ch'ongyo thus contains 171 regulations in force at the time concerning the application of the law for the six ministries, accordingly sorted. Compiled in the form of a dictionary it seems to have been aimed at county magistrates and law-enforcement officials. Finally, the most ambitious and comprehensive of these eighteenth-century reference works was Chónyul t'ongbo, compiled privately by Ku Yunmyŏng (1711-1797) and completed in 1787.

In contrast to the early period, for late Chosŏn we have a wide range of sources on the level of legal outcomes that can facilitate a better understanding of actual legal practices. The records of the State Tribunal (Üigŭmbu), the Ǔigümbu tŭngnok, cover cases dealt with at this court between 1635 and 1876. This source does not present the full details of the cases, though, but only carries memorials from the Royal Secretariat or State Tribunal describing the facts concerning the interrogations, the dates for the tribunal, personnel present, stages in the interrogation, the verdict, and the king's responses. It also contains Secret Inspector reports and essays on punishment. Another work recording State Tribunal cases is the Ch'uan küp kugan, covering the period 1601 to 1905 . Most cases relate to revolt and treason, but many also relate to conspiratorial memorials, robbery, heterodoxy, wall posters, people pretending to be royal envoys, slave uprisings, and factional strives. A collection of cases dealt with at the Ministry of Punishment is the Ch'ujo kyorongnok, covering the period 1822 to 1893. It seems that such texts were compiled once every year from the year of King Chŏngjo's enthronement (1776) up till 1893, but only texts from 1822 are extant today, and only for forty-three years. It covers a wide variety of criminal cases from all over the country, but as it only carries the verdicts and not the interrogations information on each case is scarce. Finally, there are also collections of cases dealt with at the capitol Police Bureau (P'odoch'ŏng). The Chwap'och'ong tüngnok are records from the Left Police Bureau, policing the eastern and southern parts of the capital and the eastern part of the Kyonggi province, fragmentarily covering the period 1775-1884. The Up'och'óng tüngnok are records from the Right Police Bureau, policing the western and northern parts of the capital and the western part of the Kyŏnggi province, covering the period 1807-1882, with records for the years 1808-1839 missing. The last of these collections, the Chwaup'och'ong tüngnok, are records from both bureaux covering the years 1882 and 1888 to 1890 .

From Late Chosŏn we also have a series of precedents collections. Whereas the case records are simple records of the work performed at these institutions, these texts were compiled with the stated purpose of facilitating the execution of the law by functioning as precedents. The earliest of these precedents collections is the Simnirok (Records of Simni Review Hearings), which covers 1087 cases from between 1776 and 1799, of which 980 are murder cases. The Kyujanggak also holds two early-nineteenth century judicial precedents collections titled Sugyo chongnye. As the title indicates these are collections of royal edicts, but unlike other such collections, these are only concerned with punishment of criminal offenses, and the purpose of them was to function as precedent collections. Some of the issues covered in the two collections are: the punishment of illegal private copper mines, illegal closure of market stores (ch'ŏlsi), private production and sale of gunpowder, the illegal felling of pine tress, contempt shown by slaves and other low-casts towards their superiors, and the illegal production and sale of alcohol; and regulations stipulating that cangue shouldn't be used on women or Confucian students (yusaeng), or that whipping punishment shouldn't exceed 100 lashes per day. Another precedents collection held by the Kyujanggak is Yullye yoram, 
compiled 1837. It contains 217 cases, giving a short outline and detailing the applied punishment citing the relevant paragraph in the Great Ming Code or Taejön t'ongp'yŏn. This collection seems to have been compiled for county magistrates to facilitate law enforcement in the provinces. Some of the issues covered are: arson, adultery, a concubine abusing a first wife, false claims of disaster-afflicted land, forgery, and cheating at the site of civil service exams.

These texts are an important source for analysing the level legal outcomes and they have been studied extensively. However, although some scholars focus on the procedures reflected in these records and what they tell us about the penal policies at the time, ${ }^{46}$ the majority of studies rather use these sources to read trends in society. ${ }^{47}$ The context of these studies therefore tends to be the larger historical context of the period and not specific developments in legal history, apart from procedural changes or general remarks on Confucian legal notions.

\section{Concluding remarks}

While acknowledging that we can see obvious elements of ideology construction in the process of legislation in both early and late Chosŏn, this paper argues that we must remember that while the Chosonn state introduced Confucianism as state ideology and aimed to reform Korean political and society in accordance with Confucian norms and values, in terms of the broader statecraft ramifications a much wider range of concerns were involved in legal matters, in particular in the later period of the dynasty with its demographically and economically diversifying society. The emphasis on Confucian ideology in much of the scholarship reduces the issue to a question of rule by virtue or rule by law, but we have to remember that in practice these were not seen as contradictory but rather as supplementary, and if we see these reforms as an effort by the state to manage a society increasingly difficult to control with existing ideology and statecraft, we should not be surprised to see efforts to strengthen both rule by virtue and rule by law. Admittedly both Sim Hŭigi and Han Sanggwŏn discuss the relationship between these reforms and the social situation, although they come to diametrically opposing conclusions, but the focus is narrowly on the social position and social influence of the yangban. Although this was a concern of the state, the late Chosonn period witnessed many other crucial problems and threats the state had to deal with: an ever growing and diversifying population that increasingly challenged state authority and monopolies, tax evasions, disciplinary problems in provincial and rural administration, rural unrest, and towards the end of the eighteenth century, an ideological challenge through the introduction of Catholicism.

\footnotetext{
${ }^{46}$ Kim Uch'ŏl, "Chosŏn hugi ch'uguk unyŏng”; Tanaka Toshimitsu, “'Ch'ujo simnian' ŭl t'onghae pon 19 segi chungyŏp Chosŏn ŭi hyŏngsa chŏngch'aek" [Penal Policies in Mid-Nineteenth Century Chosŏn as Seen through Ch'ujo simnian,] Pöpsahak yŏn'gu 35 (2007).

${ }^{47}$ Sim Chaeu, "18 segi huban pŏmjoe ŭi t'onggye chŏk punsŏk: 'Simnirok' ŭl chungsim ŭro" [A Statistical Analysis of Late Eighteenth Century Crime: Focussing on Simnirok,] Pŏpsahak yŏn'gu 32 (2005); Yu Sŭnghŭi, "Chŏngjodae Ch'ŏlchongdae Hansŏngbu sahyŏng pŏmjoe ŭi sil'tae wa min ŭi kalttŭng yangsang: 'Ilsŏngnok' ŭl chungsim ŭro" [Peoples Conflicts and the Reality of Death Penalty Crimes in Hansŏng from the Reign of Chŏngjo through the Reign of Ch'ŏlchong: Focussing on Ilsŏngnok,] Chosŏn sidaesa hakpo 41 (2007); Yi Sugin, "'Ŭmok' e pich'in Chŏngjodae ŭi sŏng insik: Simnirok ŭl chungsim ŭro" [Views on Sex during the Reign of Chŏngjo as seen in Cases of Licentiousness,] Kyujanggak 39 (2011); Kim Hyŏnjin, "Poksu sarin sakŏn ŭl t'onghae pon Chosŏn hugi ŭi sahoesang" [Late Chosŏn Society as Seen through Cases of Revenge Murders,] Yǒksa minsokhak 26 (2008).
} 
This essay suggests that to achieve a more comprehensive understanding of legal developments in Chosŏn Korea, we must look beyond the Confucian ideology and its central rhetoric notions of rule by ritual/virtue and rule by law and focus on the logic of actual processes. Central to this would be the interaction between the level of legal doctrine and the level of legal outcomes. Although many studies argue that the legal reforms of late Chosonn were reactions to changing socio-economic conditions, little attention has been given to the actual process through which this occurred, and, as mentioned above, when discussing the direction of legal developments in the period most studies focus on top-down developments that is, the influence of ideological notions. The vast source material can give us a good picture of how legal outcomes related to social conditions, but how these legal outcomes influenced legislation is another matter. Here it seems that the royal edicts would be a good starting point. Many of these edicts were the king's final decision in actual cases and before they were passed down to relevant authorities they had often passed through the same authorities on their way up to the king. Cho Chiman in his study on edict collections has shown that legislation was drawn up by each government office and that the king's decisions were made on the basis of the material presented by these offices. ${ }^{48}$ Even if the king's final decision often was justified with Confucian rhetoric, the process leading up to the decision that later became a royal edict involved the larger legal system and its concerns with protecting the state and maintaining social order. In this process we can observe the background of the intriguing mix of benevolent Confucian legal reforms and harsh punishments of the period. A good example would be the widening range of crimes for which hyosu was meted out in the state's efforts to protects its interests, a process based on royal decisions based on actual cases that had passed through the bureaucracy accumulating influencing factors and ramifications. ${ }^{49}$

So to return to the quote by Robert Musil at the beginning of this essay, when discussing the legal developments of the Chosonn dynasty we must not forget that although much legislation was in the form of royal edicts, not only were these edicts placed in a complicated context of legal sources, they furthermore did not reflect only the outlook of the king but were the result of the input of a large number of actors and influenced by a wide variety factors. The ideological outlook of the king in question, in terms of rule by ritual/virtue versus rule by law, would have some bearing on legislation, but that was only one of many influencing factors, and in the end the actual direction of legal developments was probably "precisely what nobody wanted."

\footnotetext{
${ }^{48}$ Cho Chiman, “'Sugyo tŭngnok' e kwanhan yŏn'gu” [A Study on Sugyo tŭngnok,] Pŏphak yŏn'gu 51:1 (2010).

${ }^{49}$ Anders Karlsson, "'Scions of Wealthy Families do not Die in the Marketplace"'.
} 


\section{Glossary}

apsŭl 壓膝

chehyŏng 除刑

chimnok 輯錄

chogyŏk 條格

chohoek 條劃

chokkŏn 條件

Chŏllok t'onggo 典錄通考

chŏlmok 節目

ch'ŏlsi 撤市

Chŏnyul t'ongbo 典律通補

chorye 條例

choryŏng 條令

Ch'uan küp kugan 推案及鞓案

Ch'ugukch'ŏng 推䩧廳

Ch'ugwanji 秋官志

Ch'ujo kyŏrongnok 秋曹決獄綠

Chüngbo chŏllok t'onggo 增補典錄通考

Chŭngsu muwŏllok 增修無寃錄

Chŭngsu muwŏllok ŏnhae 增修無寃録彥 解

churi 周牢

Chwap'och'öng tüngnok 左捕廳謄錄

Chwaup'och'óng tüngnok 左右捕廳謄錄

Da Ming lü 大明律

Hojŏn 戶典

hümhyul 欽恤

Hŭmhyul chŏnch 'ik 欽恤典則

husongnok 後續錄

Hyŏngjŏn 刑典

hyosu 稇首

Ijŏn 吏典

Kaksa sugyo 各司受敎

Kongjŏn 工典

kyeha munsŏ 啓下文書

kyŏksik 格式

Kyŏngguk taejŏn 經國大典

Kyŏngguk yukchŏn 經國六典

Kyŏngje yukchŏn 經濟六典

Kyŏngok kŏmhŏm samok 京獄檢驗事目

manse sŏngbŏp 萬世成法

minjung 民衆 nakhyŏng 烙刑

nanjang 亂杖

ŏkkang puyak ron 抑强扶弱論

Paekhŏn ch'ongyo 百憲摠要

P'odoch'ŏng 捕盜廳

pŏmnyŏng 法令

pöpch'i 法治

pŏpkyu 法規

Pyŏngjŏn 兵典

samok 事目

sarye 事例

Simnirok 審理錄

Sinbo sugyo chimnok 新補受敎輯錄

singnye 式例

Sinju muwŏllok 新註無寃錄

Soktaejŏn 續大典

songnok 續錄

sugyo 受教

Sugyo chimnok 受敎輯錄

Sugyo chŏngnye 受敎定例

Sungjŏngwŏn 承政院

Taejŏn husongnok 大典後續錄

Taejŏn songnok 大典續錄

Taejŏn t'ongp'yŏn 大典通編

Taemyŏngnuyl chikhae 大明律直解

tŏkch' $i$ 德治

Ǔigŭmbu 儀禁府

Uigŭmbu tŭngnok 儀禁府謄錄

Up'och'óng tüngnok 右捕廳謄錄

Wuyuanlu 無寃錄

yech' $i$ 禮治

Yejŏn 禮典

Yullye yoram 律例要覽

Yukchŏn sangjŏngso 六典詳定所 yusaeng 儒生 